\title{
Factors Affecting Financial Shenanigans in the Perspective of Fraud Triangle: An Empirical Study Among Manufacturing Companies Listed in Indonesia Stock Exchange
}

\author{
Susanto Salim ${ }^{1 *}$, Halim Putera Siswanto ${ }^{1}$, Henryanto Wijaya ${ }^{1}$, Jocevine Angela \\ ${ }^{1}$ Faculty of Economics and Business, Universitas Tarumanagara, Jakarta, Indonesia \\ ${ }^{*}$ Corresponding author. Email: susantos@fe.untar.ac.id
}

\begin{abstract}
This research aimed to obtain an empirical evidence about the effectiveness of fraud triangle in explaining the tendency of financial shenanigans. To achieve these objectives, this research examined the factors that influenced financial shenanigans consisting of 5 independent variables; three variables of pressure elements (Financial Stability, External Pressure, and Financial Target); one variable of opportunity elements (Monitoring Effectiveness); and one variable of rationalization elements (Auditor Change). The population of this research was the companies in manufacturing sector listed in Indonesia Stock Exchange during 2017-2018. Total sample of this research was 78 samples. For hypothesis testing, we used the logistic regression method. The results showed that Financial Stability, External Pressure, and Monitoring Effectiveness has a significant influence toward Financial Shenanigans, while Financial Target and Auditor Change has no effect on the tendency of Financial Shenanigans.
\end{abstract}

Keywords: Financial Shenanigans, Fraud Triangle, Pressure, Opportunity, Rationalization

\section{INTRODUCTION}

Financial report is systematic presentation regarding financial position and performance of an entity. The information presented in financial report has to be oriented to general needs of the users, thus does not depend on the needs and wants of certain parties. Prakoso in [1] stated that no business entity is allowed to present the information that advantages some parties, while it will disadvantage others who have the opposite interest.

Realizing the importance of information content in financial report will motivate managers to enhance the company performance, thus its existence will be mantained. In some cases, the management failed to achieve their performance goal, thus the information appeared in financial report will not be satisfying. This phenomenon will cause misleading in financial report (Financial Shenanigans).

The detection on financial shenanigans is not always clear, because there are various motivations that underlie as well as the methods to conduct financial shenanigans. In order to provide the solution to the weakness in the world's fraud detection procedure, the American Institute of Certified Public Accountant (AICPA) issued the Statement of Auditing Standards No. 99 (SAS No. 99) regarding the Consideration of Fraud in a Financial Statement Audit [2].
The issuance of SAS No.99 aimed to enhance the auditors' effectiveness in detecting fraud by assessing the risk factor of company's fraud. The factor of fraudulent risk adopted in $S A S$ No.99 is based on the general theory of fraudulent risk factor (Cressey, 1953) in [3]. According to the Cressey's theory as quoted in [4], there are three conditions that always exist in fraudulent act, which are pressure, opportunity, and rationalization, which are called as the fraud triangle. The analysis using fraud triangle in detecting the fraud in financial report previously had been conducted by [3], [4] and [5].

The fraud in financial reporting will be misleading for the users in making economic decisions due to the bias information. Based on this reason, there is an analysis on the factors affecting the fraud in financial reporting. This study focused on manufacturing companies listed in the Indonesia Stock Exchange (IDX) during the years of 20172018.

Based on the problem identification and scope that has been explained, thus the objectives of this study is to analyse whether there are significant effects of financial stability, external pressure, financial target, monitoring effectiveness, and the change of external auditor on financial shenanigans. 


\section{LITERATURE REVIEW AND CONCEPTUAL FRAMEWORK}

The Agency Theory. [6] stated that the agency theory describes the relationship between the principal or shareholders and the agent or management. This theory assumes that an individual acts according to his/her own interest. In the agency theory viewed by [7], the agency relationship appears whenever one person or more (the principal) hire another person(s) (or the agent) to provide the service and then delegates the authority in decision making to the agent. The relationship between the principal and agent can lead to the existence of asymmetrical information, because the agent stands on the position that has more information regarding the company than does the principal. Under the asumption that individuals act to maximize their own interests, with the asymmetrical information possessed will cause the agent to hide some information which is unknown by the principal. Under this asymmetrical condition, an agent can manipulate the accounting numbers presented in financial report.

Financial Shenanigans. According to [8], Financial Shenanigans is an action done by the management that misleads the investors regarding the company performance. This deception is intentionally done to bias the material facts, or to mislead the accounting menyesatkan and can affect or change the readers' decision and assessment after considering the wrong facts that have been presented.

Fraud Triangle Theory. This study is underlied by this theory. Sutherland introduced the concept of fraud triangle initially in 1949, and the it was developed and reintroduced by the Criminologist Dr. Donald R. Cressey (1953) in his study on embezzlement [9]. According to Cressey, there are three dominant factors underlying the fraud creation, which are pressure, opportunity, and razionalitation / attitude.

Based on [2], there are four types of general condition applied in pressure that may cause the fraud, which are financial stability, external pressure, individual financial needs, and financial target. Meanwhile, the opportunity consitis of three condition categories, which are industrial category, monitoring effectiveness, and organizational structure. The last component causing the fraud is rationalization. This rationalization causes the fraud perpetrator to seek for justification of his/her conduct.

Financial Stability. This variable is proxied by the ratio of total asset change (ACHANGE). According to [2], managers face the pressure to conduct fraud in financial report when the financial stability and/or profitability is threatened by the condition of economic, industry, or the operating entity. Companies try to enhance their good outlook, one of them is by manipulating the information regarding the assets possessed. This proves that the higher the ratio of total asset change of a company, the probability to conduct fraud in financial report of the company will be higher.

$\mathrm{H}_{1}$ : Financial Stability has a positive effect on Financial Shenanigans

External Pressure. This variable is proxied by the ratio of leverage (LEV). Leverage is the amount of debt used to finance a company's operation. In order to acquire a loan from external party, a company must convince that it can afford to repay the loan. The pressure from external party makes the company try to present good performance or financial ratios and high profit to attract the candidate investors. According to [10], when a company has a high leverage ratio, it has a probability to create a false financial reporting.

$\mathrm{H}_{2}$ : External Pressure has a positive effect on Financial Shenanigans

Financial Target. This variable is proxied by the ratio of Return on Asset (ROA). ROA is used to measure the capability of management to generate the profit overally. This analysis is then projected to the future to oversee the company's capability in generating the profits in the future. According to [1], the higher the target ROA determined by a company, the earning management is more likely to happen as one of the financial report fraudulences.

$\mathrm{H}_{3}$ : Financial Target has a positive effect on Financial Shenanigans

Monitoring Effectiveness. The existence of fraudulent practices in companies is the impact of monitoring ineffectiveness as a weakness of corporate governance. This phenomenon provides opportunity to company's agent, which is the manager to behave deviantly. Fraud can be minimized by applying a good monitoring system. According to [3], by the existence of board of independent commissioner, the company's monitoring system is expected to be more effective and the fraud can be minimized. Therefore, monitoring effectiveness can be proxied by the ratio board of independent commissioner (BDOUT).

$\mathrm{H}_{4}$ : Monitoring Effectiveness has a negative effect on Financial Shenanigans

External Auditor Change. Auditor is an important supervisor in financial report. Information regarding a company which is indicated having fraud usually comes from the auditor. [11] stated that the more often a company changes its auditor, then the higher the risk of financial shenanigans in the company, because the fraud perpetrators feel confident that their actions will not be detected due to the auditor change.

$\mathrm{H}_{5}$ : External Auditor Change has a positive effect on Financial Shenanigans

Based on those explanations, the conceptual framework in this study is as follow: 


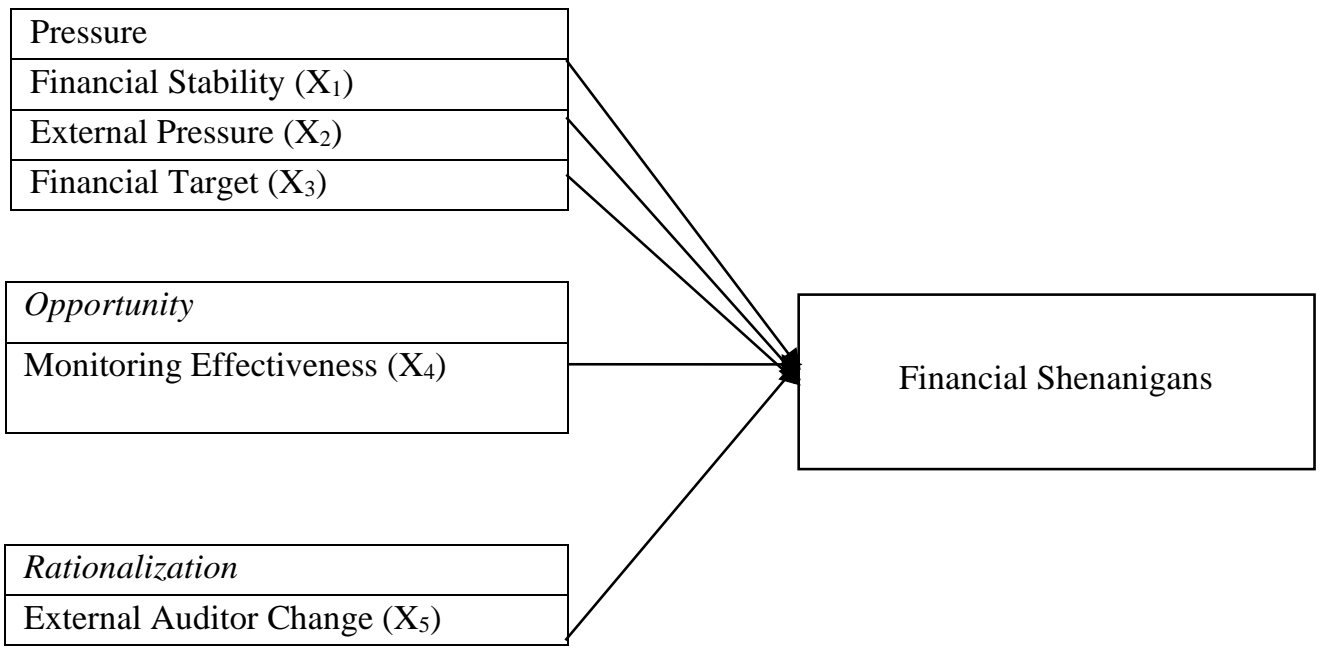

Figure 1. Conceptual Framework

Table 1. The Results of Previous Studies

\begin{tabular}{|c|c|c|c|c|}
\hline No. & $\begin{array}{l}\text { Researchers' } \\
\text { Name }\end{array}$ & Research Title & Variables & Research Result \\
\hline 1. & $\begin{array}{l}\text { Skousen et al. } \\
\text { (2009) }\end{array}$ & $\begin{array}{l}\text { Detecting and } \\
\text { Predicting Financial } \\
\text { Shenanigans: The } \\
\text { Effectiveness of The } \\
\text { Fraud Triangle and SAS } \\
\text { No. } 99\end{array}$ & $\begin{array}{l}5 \text { proxies of Pressure and } \\
2 \text { proxies of Opportunity } \\
\text { significantly affect the } \\
\text { Fraud }\end{array}$ & $\begin{array}{l}\text { Rapid asset growth, the increase } \\
\text { of cash necessity, external } \\
\text { financing, external and internal } \\
\text { share ownership, BOD control, } \\
\text { the number of Independent } \\
\text { Commissioner in Audit } \\
\text { Committee affect the increase of } \\
\text { Financial Shenanigans. }\end{array}$ \\
\hline 2. & $\begin{array}{l}\text { Ema } \\
\text { Kurniawati } \\
(2012)\end{array}$ & $\begin{array}{l}\text { The Analysis of Factors } \\
\text { Affecting Financial } \\
\text { Shenanigans in Fraud } \\
\text { Triangle Perspective }\end{array}$ & $\begin{array}{l}\text { Financial Stability, } \\
\text { External Pressure, } \\
\text { Transaction with Special } \\
\text { Parties, and Public } \\
\text { Accountant Change }\end{array}$ & $\begin{array}{l}\text { All variables affect } \\
\text { Financial Shenanigans, except the } \\
\text { auditor change done by the } \\
\text { company }\end{array}$ \\
\hline 3. & $\begin{array}{l}\text { Sukirman and } \\
\text { Sari (2012) }\end{array}$ & $\begin{array}{l}\text { The Model of Fraud } \\
\text { Detection Based on } \\
\text { Fraud Triangle } \\
\text { (A Case Study Among } \\
\text { Public Companies in } \\
\text { Indonesia) }\end{array}$ & $\begin{array}{l}\text { Financial Stability, } \\
\text { External Pressure, } \\
\text { Financial Target, } \\
\text { Industry Characteristics, } \\
\text { and Audit Report. }\end{array}$ & $\begin{array}{l}\text { Only one variable, which is the } \\
\text { Audit Report, has significant } \\
\text { effect on fraud, while others do } \\
\text { not. }\end{array}$ \\
\hline 4. & $\begin{array}{l}\text { Hanum and } \\
\text { Sudrajat (2014) }\end{array}$ & $\begin{array}{l}\text { The Analysis of Factors } \\
\text { Affecting Financial } \\
\text { Shenanigans in Fraud } \\
\text { Triangle Perspective }\end{array}$ & $\begin{array}{l}\text { Financial Stability, } \\
\text { Effective Monitoring, } \\
\text { and Auditor Change }\end{array}$ & $\begin{array}{l}\text { Financial Stability has positive } \\
\text { and significant effect on the risk } \\
\text { of Financial Shenanigans. }\end{array}$ \\
\hline 5. & $\begin{array}{l}\text { Tiffani and } \\
\text { Marfuah (2015) }\end{array}$ & $\begin{array}{l}\text { Financial Shenanigans } \\
\text { Detection with Fraud } \\
\text { Triangle Analysis } \\
\text { Among Manufacturing } \\
\text { Companies Listed in } \\
\text { IDX }\end{array}$ & $\begin{array}{l}\text { Financial Stability, } \\
\text { External Pressure, } \\
\text { Personal Financial } \\
\text { Needs, Financial Target, } \\
\text { Industry Characteristics, } \\
\text { Monitoring } \\
\text { Effectiveness, and } \\
\text { Auditor Change }\end{array}$ & $\begin{array}{l}\text { Financial Stability, External } \\
\text { Pressure, and Monitoring } \\
\text { Effectiveness have significant } \\
\text { effects on Financial Shenanigans. }\end{array}$ \\
\hline
\end{tabular}




\section{RESEARCH METHODOLOGY}

\subsection{Population and Sampling Technique}

In this study, the population is the manufacturing companies listed in Indonesia Stock Exchange (IDX) during 2017-2018 [12]. The purposive sampling was used with the criteria as follows:

a. The manufacturing companies have been listed in IDX during the period of 2017-2018.

b. The manufacturing companies published their financial reports and annual reports in IDX website in the years of 2017 and 2018 consecutively.

c. The manufacturing companies use IDR denomination in presenting their financial reports.

d. The data was completely available and published in the years of 2017-2018 especially regarding the five variables used in this study. e. The companies were indicated conducting fraud once at minimum within those two years of observation based on the Beneish M-Score Formula.

From the secondary data collection, the number of samples are 39 companies, so for two-year observation there are 78 samples in total.

\subsection{Variables' Operationalization}

\subsubsection{Dependent Variable}

The dependent variable in ths study is Financial Shenanigans (FRAUD), which was measured by using the Beneish M-Score Formula. The Beneish M-Score was measured using eight financial ratios to identify whether the companies had the indication to manipulate their income in the financial reports [13].

Table 2. Financial Ratios to Measure Beneish-M Score

\begin{tabular}{|c|c|c|}
\hline No & Financial Ratio & Formula \\
\hline 1. & $\begin{array}{l}\text { Day Sales in Receivable Index } \\
\text { (DSRI) }\end{array}$ & $\frac{\text { Net Receivables }_{t} / \text { Sales }_{t}}{\text { Net Receivables }_{t-1} / \text { Sales }_{t-1}}$ \\
\hline 2. & Gross Margin Index (GMI) & $\frac{\text { Gross Profit }_{t-1} / \text { Sales }_{t-1}}{\text { Gross Profit }_{t} / \text { Sales }_{t}}$ \\
\hline 3. & Asset Quality Index (AQI) & $\frac{T A_{t}-\left(C A_{t}+P P E_{t}\right) / T A_{t}}{T A_{t-1}-\left(C A_{t-1}+P P E_{t-1}\right) / T A_{t-1}}$ \\
\hline 4. & Sales Growth Index (SGI) & $\frac{\text { Sales }_{t}}{\text { Sales }_{t-1}}$ \\
\hline 5. & Depreciation Index (DEPI) & $\frac{\text { Depreciation }_{t-1} /\left(\text { Depreciation }_{t-1}+P P E_{t-1}\right)}{\text { Depreciation }_{t} /\left(\text { Depreciation }_{t}+P P E_{t}\right)}$ \\
\hline 6. & $\begin{array}{l}\text { General Sales and } \\
\text { Administrative Expenses Index } \\
\text { (SGAI) }\end{array}$ & $\frac{\text { SG\&A Expense }_{t} / \text { Sales }_{t}}{\text { SG\&A Expense }_{t-1} / \text { Sales }_{t-1}}$ \\
\hline 7. & $\begin{array}{l}\text { Total Accruals to Total Assets } \\
\text { (TATA) }\end{array}$ & $\begin{array}{c}\Delta \text { Working Capital }-\Delta \text { Cash }-\Delta \text { Income Tax Payable } \\
- \text { Depreciation Expense }{ }_{t} \\
\text { Total Assets }\end{array}$ \\
\hline 8. & Leverage Index (LVGI) & $\frac{\text { Total Debt }_{t} / \text { Total }_{\text {Assets }}}{\text { Total Debt }_{t-1} / \text { Total Assets }_{t-1}}$ \\
\hline
\end{tabular}

Source: Beneish (1997)

After calculating those ratios, the Beneish M-Score can be formulated as follow:

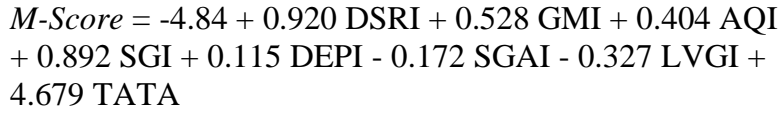

If the Benesih M-Score is greater than -2.22, the company can be categoried as conducting fraud. If the score is less than -2.22 , the company can be categoried as NOT conducting fraud (non-fraud), The company indicated conducting fraud was given score 1 , and the one does not was given score 0 . 


\subsubsection{Independent Variables}

In this study, the independent variables consist of Financial Stability, External Pressure, Financial Target, Monitoring Effectiveness, and External Auditor Change.

1) Financial Stability

This variable is proxied by ACHANGE, which is the ratio of asset change for two years. ACHANGE can be calculated by using the formula as follow:

ACHANGE $=\frac{\left(\text { Total Asset }_{t}-\text { Total Asset }_{t-1}\right)}{\text { Total Asset }_{t}}$

2) External Pressure

This is an excess pressure for management to fulfil the requirement of expectation from third party. Leverage is used as a proxy for external pressure, whereas high leverage will cause a pressure to the management, thus will have positive relationship with financial report fraudulence.

$\mathrm{LEV}=\frac{\text { Total Debt }}{\text { Total Asset }}$

3) Financial Target

In running business, a company often determines the level of profit that has to be generated as a compensation of the efforts to achieve it. Hence, this condition is known as financial target. One of the methods used to measure the profit level is Return on Asset (ROA). Therefore, ROA can be a proxy to measure financial target in this study.

$\mathrm{ROA}=\frac{\text { Earning After Interest and Tax }}{\text { Total Asset }}$

4) Monitoring Effectiveness

The Statement of Audit Standard (PSA) no.70 shows that some of the financial report fraudulences can exist due to management domination by an individual or small group, without the control that compensates such condition, such as the monitoring from Board of Commissioners or Audit Committee. Therefore, monitoring effectiveness is proxied by the ratio of Board of Independent Commissioners.

BDOUT $=\frac{\text { Jumlah dewan komisaris independen }}{\text { Jumlah total dewan komisaris }}$

5) External Auditor Change

This is a dummy variable, in which during the observation period, a company conducting auditor change will be given score 1 , and the one that did not will be given score 0 .

Data analysis in this study used descriptive statistics, Hosmer and Lemeshow's Goodness of Fit Test, Overall Model Fit Test, Nagelkerke R-Square, prediction accuracy test, and hypothesis tests. The logistic regression equation in this study can be formulated as follow:

FRAUD $=\beta_{0}+\beta_{1}$ ACHANGE $+\beta_{2} \mathrm{LEV}+\beta_{3} \mathrm{ROA}+$ $\beta_{4} \mathrm{BDOUT}+\beta_{5} \mathrm{AUDCHANGE}+\varepsilon$

Description:

FRAUD = Dummy variable; 1 for company cinducting fraud, and 0 for the company that didn't.

ACHANGE $=$ Ratio of Total Asset change
LEV = Total Debt to Total Asset

ROA $=$ Net Profit to Total Asset

$\mathrm{BDOUT}=$ Percentage of the number of $\mathrm{BoC}$ from outside of the company

AUDCHANGE = Dummy variable; 1 for company changing its auditor during the observation period, and 0 for the company that didn't.

$\mathrm{E}=$ Error

\section{RESEARCH RESULTS AND DISCUSSIONS}

Testing the Fitness of Regression Model. In this stage, we conducted the analysis to find out whether the logistic regression model proposed in this study is already fit. This fitness test was done by using Hosmer and Lemeshow's Goodness of Fit Test. If the significance value is less than or equal to 0.05 , then the null hypothesis is rejected. Therefore, the model does not fit the data. In the opposite, if the significance value is greater than 0.05 , then the null hypothesis is accepted. Thus, the model fits the data.

Table 3

Hosmer and Lemeshow Test

\begin{tabular}{|l|r|r|r|}
\hline Step & Chi-square & df & \multicolumn{1}{c|}{ Sig. } \\
\hline 1 & 5.097 & & 8 \\
\hline
\end{tabular}

In Table 3, the significance value is 0.747 (greater than 0.05 ), thus the hypothesized model already fits the data. There is no difference between model and data, or in other word, the logistic regression model can be used for further analysis.

Overall Model Fit Test. According to [14], this test can be done by observing the value of $-2 \log L$ in block 0 and block 1. If there is a decrease of the value $-2 \log L$ in block 1 compared to the one in block 0 , then the overall model fits the data.

Table 4. Overall Model Fit

\begin{tabular}{|l|l|}
\hline Description & -2 Log Likelihood \\
\hline Block Number $=0$ & 129.689 \\
\hline Block Number $=1$ & 98.193 \\
\hline
\end{tabular}

Source: SPSS Ouput

After putting in all independent variables consisting of Financial Stability (ACHANGE), External Pressure (LEV), Financial Target (ROA), Monitoring Effectiveness (BDOUT), and External Auditor Change (AUDCHANGE) into the model, -2 Log Likelihood Block Number $=1$ shows the value of 98.193. If compared to the beginning value of -2 Log Likelihood awal as much as 129.689 , it can be seen that there is a decrease of $-2 \log$ Likelihood as much as 31.496. The decrease of this -2 Log Likelihood value shows that the regression model is good, or in other word, the hypothesized model fits the data. 
Moreover, the Omnibus Test of Model Coefficient can be used to show whether the logistic regression model used in this study can explain the dependent variable (Financial Shenanigans). The Omnibus Test of Model Coefficient was conducted by comparing the significance value of $\mathrm{Chi}$ Square ( $p$-value) to the significance level of 0.05 . The model is significant in explaining the dependent variable, if the significance value of Chi Square (p-value) is less than the significance level (0.05). The result of Omnibus Test of Model Coefficient can be viewed in Table 5 as follow:
Table 5

Omnibus Test of Model Coefficients

\begin{tabular}{|ll|r|r|r|}
\hline & & Chi-square & df & \multicolumn{1}{c|}{ Sig. } \\
\hline Step 1 & Step & 31.496 & 5 & .000 \\
& Block & 31.496 & 5 & .000 \\
& Model & 31.496 & 5 & .000 \\
\hline
\end{tabular}

Source: SPSS Output

Based on the test result, the significance value of Chi Square (p-value) is 0.000 which is less than the significance level (0.05). Thus, this model is significant in explaining the occurance of Financial Shenanigans.

\section{Testing the Prediction Accuracy}

Tabel 6

Classification Table

\begin{tabular}{|l|l|l|r|r|r|}
\hline \multirow{2}{*}{} & \multirow{2}{*}{\multicolumn{2}{|c|}{}} & \multicolumn{3}{|c|}{ Predicted } \\
\cline { 3 - 6 } & \multirow{2}{*}{\begin{tabular}{|c|c|} 
FRAUD \\
Observed
\end{tabular}} & $\begin{array}{c}\text { Did Not } \\
\text { Conduct Fraud }\end{array}$ & $\begin{array}{c}\text { Conducted } \\
\text { Fraud }\end{array}$ & $\begin{array}{c}\text { Percentage } \\
\text { Correct }\end{array}$ \\
\cline { 3 - 6 } Step 1 & \multirow{2}{*}{ FRAUD } & Did Not Conduct Fraud & 45 & 12 & 78.9 \\
\cline { 3 - 6 } & & Conducted Fraud & 15 & 24 & 61.5 \\
\cline { 2 - 6 } & Overall Percentage & & & 71.9 \\
\hline
\end{tabular}

Source: SPSS Output

The prediction of model accuracy using a $2 \times 2$ Classification Table shows that the number of companies not conducting fraud (0) was 57, while the observation result only shows 45 companies, thus the classification accuracy is $78.9 \%$. In predicting the companies conducting fraud (1), the number is 39 , while the observation result only shows 24 , thus the

Table 7. Nagelkerke R-Square Test Result Model Summary

\begin{tabular}{|l|r|r|r|}
\hline Step & $\begin{array}{c}-2 \text { Log } \\
\text { Likelihood }\end{array}$ & $\begin{array}{c}\text { Cox \& Snell } \\
\text { R Square }\end{array}$ & $\begin{array}{c}\text { Nagelkerke R } \\
\text { Square }\end{array}$ \\
\hline 1 & $98.193^{\mathrm{a}}$ & .280 & .377 \\
\hline
\end{tabular}

Source: SPSS Output

\section{Parameter Estimation and Interpretation}

classification accuracy is $61.5 \%$. Therefore, the overall classification accuracy is $71.9 \%$.

Coefficient of Determination (Nagelkerke R-Square). Dalam logistic regression, CD (or $R^{2}$ ) is used to measure the variation in dependent variable that can be explained by the independent variables.

The value of Nagelkerke R-Square is 0.377 (or 37.7\%). Based on the value of Nagelkerke R-Square, it can be concluded that the independent variables consisting of Financial Stability (ACHANGE), External Pressure (LEV), Financial Target (ROA), Monitoring Effectiveness (BDOUT), and External Auditor Change (AUDCHANGE) affect Financial Shenanigans as much as $37.7 \%$, while the remaining $62.3 \%$ variation in Financial Shenanigans is affected by other variables that are not included in this study.

Table 8. Parameter Estimation Test Result Variables in the Equation

\begin{tabular}{|c|c|c|c|c|c|c|c|}
\hline & & $\mathrm{B}$ & S.E. & Wald & $\mathrm{df}$ & Sig. & $\operatorname{Exp}(B)$ \\
\hline \multirow[t]{6}{*}{ Step $1^{\mathrm{a}}$} & ACHANGE & 4.226 & 2.028 & 4.341 & 1 & .037 & 68.440 \\
\hline & LEV & 1.717 & .768 & 4.997 & 1 & .025 & 5.567 \\
\hline & ROA & 1.948 & 3.024 & .415 & 1 & .519 & 7.017 \\
\hline & BDOUT & -16.247 & 4.209 & 14.899 & 1 & .000 & .000 \\
\hline & $\begin{array}{l}\text { AUDCHANG } \\
\text { E }\end{array}$ & .148 & .648 & .052 & 1 & .819 & 1.160 \\
\hline & Constant & 4.270 & 1.418 & 9.071 & 1 & .003 & 71.538 \\
\hline
\end{tabular}

Source: SPSS Output 
The test was conducted using the significance value of 0.05 . If the p-value is less than 0.05 , then the hypothesis is accepted. Meanwhile, if the p-value is greater than 0.05, then the hypothesis is rejected.

\section{The Results of Hypothesis Testing}

a. The effect of Financial Stability on Financial Shenanigans. The variable of Financial Stability has a beta coefficient of 4.226 with the significance value of 0.037. This result shows that $\mathrm{H}_{1}$ was accepted, which means that Financial Stability has a significant effect on Financial Shenanigans. This result is in line with the study conducted by [3], but not in line with the study conducted by [11].

b. The effect of External Pressure on Financial Shenanigans. The variable of External Pressure has a beta coefficient of 1.717 with the significance value of 0.025. This result shows that $\mathrm{H}_{2}$ was accepted, which means that External Pressure has a significant effect on Financial Shenanigans. This result is in line with the study conducted by [1] as well as [5], but not in line with the study conducted by [15].

c. The effect of Financial Target on Financial Shenanigans. The variable of Financial Target has a beta coefficient of 1.948 with the significance value of 0.519 . This result shows that $\mathrm{H}_{3}$ was rejected, which means that there is no significant effect of Financial Target on Financial Shenanigans. This result is in line with the study conducted by [15], but different from the study conducted by [16]

d. The effect of Monitoring Effectiveness on Financial Shenanigans. This variable has a beta coefficient of 16.247 with the significance value of 0.000 . This result shows that $\mathrm{H}_{4}$ was accepted, which means that monitoring effectiveness has a significant effect on Financial Shenanigans. This is in line with the study conducted by [17], but different from the study conducted by [18].

e. The effect of External Auditor Change on Financial Shenanigans. This variable has a beta coefficient of 0.148 with the significance value of 0.819 . This result shows that $\mathrm{H}_{5}$ was rejected, which means that there is no significant effect of External Auditor Change on Financial Shenanigans. This is in line with the study conducted by [1], but different from the study conducted by [11].

\section{CONCLUSIONS, LIMITATIONS, AND SUGGESTIONS}

Conclusions. Based on the result of data analysis and hypothesis testing, it can be concluded that Financial Stability as proxied by the ratio of asset change (ACHANGE), External Pressure as proxied by Leverage Ratio (LEV), and Monitoring Effectiveness as proxied by the percentage of Independent Commissioners (BDOUT), show significant effects on the tendency of Financial Shenanigans. Meanwhile, Financial Target as proxied by the Return on Asset (ROA) and External Auditor Change (AUDCHANGE) do not have significant effects on Financial Shenanigans.

Limitations. The Authors realize that this study is not perfect yet, thus there is still a lot of weaknesses and limitations that occurred during the research conduct, such as: (1) The samples were only limited to manufacturing companies listed in IDX in the periods of 2017-2018; (2) This study only used five independent variables as proxies to the components of Fraud Triangle, which are Financial Stability, External Pressure, Financal Target, Monitoring Effectiveness, and External Auditor Change. Meanwhile, there are still many other proxies of Fraud Triangle; (3) The research period is only limited to two years (2017-2018), while to predict the tendency of Financial Shenanigans needs a long period of time in order to acquire the more consistent result.

Suggestions. Based on the conclusions and limitations of this study, some suggestions can be provided as follows: (1) Add the category of samples, such as the financial companies (banking) and non-financial companies in other sectors, to predict the tendency of financial report fraudulence; (2) Add other proxies of Fraud Triangle components so that the research scope can be broadened, especially for the proxy of rationalization which needs more attention, because this research is still unable to show the significant effect; (3) Expand the period of observation in order to predict the financial report fraudulence more accurately and effectively.

\section{REFERENCES}

[1] Kurniawati, Ema. (2012). “Analisis Faktor-Faktor yang Mempengaruhi Financial Shenanigans dalam Perspektif Fraud Triangle". Accounting Analysis Journal: Universitas Diponegoro, Indonesia.

[2] American Institute of Certified Public Accountants. (2007). AU Section 316: Consideration of Fraud in a Financial Statement Audit (SAS No. 99; SAS No. 113).

[3] Skousen, C. J., Smith, K. R., and Wright, C. J. (2009). "Detecting and Predicting Financial Shenanigans: The Effectiveness of The Fraud Triangle and SAS No. 99". Corporate Governance and Firm Performance Advances in Financial Economics. Volume 13, pp: 53-81.

[4] Well, Joseph T. (2014). Principle of Fraud Examination. $4^{\text {th }}$ Edition. New York: John Wiley \& Sons Inc.

[5] Lou, Y.I., dan Wang, M.L. (2009). "Fraud Risk Factor of The Fraud Triangle: Assessing the Likelihood of Fraudulent Financial Reporting ”. Journal of 
Business \& Economics Research. Volume 7, No. 2, pp. 61-78.

[6] Martantya dan Daljono (2013). "Pendeteksian Kecurangan Financial Report Melalui Faktor Risiko Tekanan dan Peluang". Diponegoro Journal of Accounting. Volume 2, No. 2, pp. 1-12.

[7] Jensen, Michael C. and William H. Meckling. (1976). Theory of the firm: Managerial behavior, agency costs and ownership structure. Journal of Financial Economics, Volume 3. pp. 305-360.

[8] Schilit, Howard, M (2018). "Financial Shenanigans: How to detect Accounting Gimmicks and Fraud in Accounting Reports", $4^{\text {th }}$ Ed, McGraw Hill, New York.

[9] Drew, J. M., \& Drew, M. E. (2010). Ponzimonium: Mad-off and the Red Flags of Fraud. Discussion Papers Griffith Business School.

[10] Ansar, Muhammad. (2011). Journal. Analisis Faktor-Faktor yang Mempengaruhi Kecurangan Pelaporan Keuangan pada Perusahaan Publik di Indonesia. Diponegoro Journal of Accounting. Universitas Diponegoro. Semarang.

[11] Nauval, M. (2014). Analisis Faktor-Faktor Yang Berpengaruh Terhadap Kecenderungan Financial Statement Fraud dalam Perspektif Fraud Triangle. Jurnal Ekonomi dan Bisnis UB, Volume 3, No. 2.

\section{[12] www.idx.co.id}

[13] Beneish, M. (1997). "Detecting GAAP Violation: Implications for Assessing Earnings Management Among Firms with Extreme Financial Performance”. Journal of Accounting and Public Policy. Volume 16 (3).

[14] Ghozali, Imam. (2013). Aplikasi Analisis Multivariate Dengan Program IBM SPSS 21. Semarang: Universitas Diponegoro.

[15] Sukirman S. and Sari, Maylia Pramono (2012). Model Deteksi Kecurangan Berbasis Fraud Triangle (Studi Kasus pada Perusahaan Publik di Indonesia). Jurnal Akuntansi dan Auditing (2), pp. 199-225.

[16] Norbarani, Listiana. (2012). "Pendeteksian Kecurangan Laporan Keuangan Dengan Analisis Fraud Triangle yang Diadopsi Dalam SAS No. 99”. Skripsi: Fakultas Ekonomika dan Bisnis, Universitas Diponegoro.
[17] Tiffani, Laila and Marfuah. (2015). Deteksi Financial Statement Fraud dengan Analisis Fraud Triangle pada Perusahaan Manufaktur yang Terdaftar di Bursa Efek Indonesia. Jurnal Akuntansi dan Auditing Indonesia, Volume 19, No. 2, pp. 112-125.

[18] Hanum, Ivonna N. and Sudrajat. (2014). FaktorFaktor yang Mempengaruhi Auditor Switching pada Perusahaan yang Terdaftar di Indonesia. The Journal of Accounting and Finance, Volume 19 (2), pp. 165-188. 